\title{
ПРОБЛЕМЫ МИГРАЦИОННОГО УЧЁТА ИНОСТРАНЦЕВ ПО МЕСТУ ЖИТЕЛЬСТВА И ПРЕБЫВАНИЯ
}

\author{
К. Г. Никиенко \\ Московский гуманитарный университет
}

\begin{abstract}
Аннотация: Правовое регулирование и процессы миграции - явления не отделимые, так как в совокупности представляют один из аспектов глобализации социальных и правовых отношений. Урегулирование данных процессов позволит улучшить благосостояние общества и развивать экономику.
\end{abstract}

Ключевые слова: миграционный учет; права иностранцев; миграционный поток; жилое помещение; коррупция

\section{CPROBLEMS OF THE MIGRATION REGISTRATION OF FOREIGNERS AT THE PLACE OF RESIDENCE AND STAY}

\author{
K. G. Nikienko \\ Moscow University for the Humanities
}

Abstract: Legal regulation and migration processes are inseparable phenomena since together they represent an aspect of the globalization of social and legal relations. The settlement of these processes will improve the welfare of society and economic efficiency.

Keywords: migration registration; foreigners' rights; migration flow; living quarters; corruption

Миграционные потоки, вызванные процессами глобализации, заставляют государства вести регистрационный учет, который в основном позволяет определять тенденцию развития трудового рынка по отраслям, снижать уровень преступности.

Осуществляемый государством регистрационный учет в соответствии с законодательством именуется миграционным учетом. Так согласно Федеральному закону «0 миграционном учете иностранных граждан и лиц без гражданства в Российской Федерации» (далее - Закон о миграционном учете): миграционный учет иностранных граждан и лиц без гражданства (далее - миграционный учет) - государственная деятельность по фиксации и обобщению предусмотренных настоящим Федеральным законом сведений об иностранных гражданах и о лицах без гражданства и о переме- 
Научные труды Московского гуманитарного университета 2019 № 6

щениях иностранных граждан и лиц без гражданства (Федеральный закон «0 миграционном учете ..., 2006: Электр. ресурс).

В соответствии с Законом о миграционном учете, миграционный учет бывает двух видов: по месту проживания и по месту пребывания. Помимо прочего в законодательстве содержится понятие постоянная прописка.

Стоит отметить, что вопросы, связанные с миграционным учетом, имеют особую актуальность со времен советского периода. В современных реалиях у большинства людей понятие миграционный учет вызывает страх, т.к. невольно возникает мысль, что если лицо прописано, то оно должно там жить. Наличие такого положения дел объяснимо, по большей части экономическими причинами. Не является секретом, что собственник не желает уменьшение стоимости своего предмета и старается минимизировать риски, к которым относятся в том числе миграционный учет.

Особой проблемой в вопросах миграционного учета является ранее упомянутая постоянная прописка. При постоянной прописке в паспорте содержится регистрационный штамп, который не имеет срока действия. Данное свойство создает проблемы, т. к. ст. 40 Конституции России прописывает, что каждый имеет право на жилище. Никто не может быть произвольно лишен жилища (Конституция Российской Федерации..., 1993).

Большинство выступают категорически против миграционного учета. Абсолютизм института собственности, мошеннические действия, несовершенство законодательства и множество иных моментов злоупотребления правом создали проблемы современного общества. Совокупность вышеуказанных проблем создает необходимость решать вопросы миграционного учета.

Одним из недостатков законодательства является срок регистрации мигрантов, который составляет 7 дней после пересечения границы. В случае нарушения данной нормы нарушителю грозит штраф в размере 5000 тысяч рублей с депортацией и запретом въезда на территорию Российской Федерации в течение 3 лет. Санкция того рода негативно влияет симметрично как на иностранного гражданина, так и на бюджет. Иностранный гражданин теряет возможность осуществлять деятельность, т. е. снижение конкуренции, а бюджет недополучает налоговые поступления.

Решение данной проблемы отразилось в создании квартир, которые имеют большое число прописанных лиц, называемые в простонародье «резиновые квартиры». Последние породили еще больше проблем. Обращает на себя внимание то, что до криминализации фиктивной регистрации граждан Российской Федерации данное правонарушение КоАП РФ не предусматривалось. Статья 19.15.2 КоАП РФ, устанавливающая ответственность за нарушение правил регистрации граждан Российской Федерации, была 
включена в административное законодательство одновременно со ст. 322.2 УК РФ в связи с принятием Федерального закона от 21 декабря 2013 г. N 376Ф3 «0 внесении изменений в отдельные законодательные акты Российской Федерации». Это не только создало трудности в разграничении указанных правонарушений, но и, по существу, явилось нарушением принципа экономии репрессии (Урда, 2019).

Особый страх у лиц, владеющих недвижимым имуществом, возникает перед налоговыми службами, т. к. проживание иных лиц, не связанных родственными связами, вызывает вопросы по получению дохода от найма. Уклонение от уплаты налога является также весьма негативным фактором для экономики.

Граждане РФ, сдав в аренду помещение иностранцу и не предоставив ему миграционный учёт, также нарушают законодательство миграционного учёта. Необходимо привлечение к ответственности и граждан РФ за бездействие в предоставлении регистрации, равно тому нарушению гражданами РФ, которые предоставляют фиктивную регистрацию трудовым мигрантам. Иностранцы, чтобы не нарушать миграционного учёта в течение 7 рабочих дней вынуждены тоже нарушать закон миграционного учёта и обращаться к сторонним, нелегальным организациям и гражданам РФ для помощи в оформлении документов миграционного учёта (фиктивной регистрации).

Увеличение проблем в совокупности продолжают порождать все больше правонарушений со стороны лиц, которые заинтересованы в отсутствии должного правового регулирования. Наличие такого положения дел предоставляет возможность незаконного обогащения, расширения рынка нелегальных услуг, повышению уровня коррупции.

Немалое количество отрицательных моментов в законодательстве породило изменения и дополнения, которые были внесены в недавнем прошлом. Новшеством в этом плане стало понятие место пребывания, которое излагается в следующей редакции: место пребывания иностранного гражданина или лица без гражданства в Российской Федерации (далее - место пребывания) - жилое помещение, не являющееся местом жительства, или иное помещение, в котором иностранный гражданин или лицо без гражданства фактически проживает (регулярно использует для сна и отдыха), либо организация, по адресу которой иностранный гражданин или лицо без гражданства подлежит постановке на учет по месту пребывания в случае, предусмотренном частью 2 статьи 21 настоящего Федерального закона (Федеральный закон..., 2018).

Указанная трактовка понятия места пребывания носит ограничительный характер, требуя более высокие стандарты проживания лиц, которые 
Научные труды Московского гуманитарного университета 2019 № 6

ограничивают регистрацию по месту осуществления трудовой деятельности в силу того, что большинство работодателей не обладает столь удобной материальной базой для проживания сотрудников.

Осуществление действенных методов со стороны государства является необходимым условием уменьшения незаконных действий в области миграционного учета и защиты прав иностранцев, которые в большей степени подвержены к привлечению ответственности.

Одними из таких методов является лицензирование частных организаций, осуществляющих деятельность в области миграционных процессов, т. е. оказывающих вспомогательных характер услуг иностранным лицам.

Так Т. С. Трофимова отмечает, что получает на рынке труда множество частных структур, оказывающих трудящимся-мигрантам различного рода услуги, причем дорогостоящие. Такие структуры существуют де-факто, будучи не урегулированными действующим законодательством. Необходимость активного развития деятельности негосударственных агентств занятости очевидна. По опыту зарубежных стран повышению ответственности способствовало бы лицензирование данного вида деятельности (Трофимова, 2019).

Немаловажным является применение специальных мер, к которым можно отнести строительство и дальнейшее предоставление в наем жилых домов для мигрантов из других государств. При реализации данного механизма следует исключить предоставление налоговых послаблений при обложении индивидуальным подоходным налогом и применять $30 \%$ налоговую ставку за исключением высококвалифицированных специалистов. Также жилые дома такого рода следует строить в разных частях города и небольших размеров для более быстрого процесса адаптации в культурной среде страны.

Выделение высококвалифицированных специалистов в отдельную категорию объясняется тем, что данные лица обладают высокой стоимостью на рынке труда в силу их умений и навыков, которые делают огромный вклад в развитие экономики страны, где осуществляют трудовую деятельность.

Жесткая регламентация миграционных процессов создает немало отрицательных моментов в виде коррупционной составляющей и выделением финансовых средств. Опыт прошлых лет также продемонстрировал, что даже при миграционном учете совершаются тяжкие и особо тяжкие преступления. Правовой идеализм в области миграционного учета выступает побудителем правового нигилизма.

Уменьшение таких процессов требует решительных действий в совокупности с достижениями информационных технологий. Отсутствие обя- 
зательного миграционного учета с заменой на уведомительный характер место нахождения позволит сократить рынок незаконных посреднических услуг.

Дальнейшее совершенствование уведомительного следует осуществлять с применением информационных технологий, где будет создан портал электронных услуг для уведомления. Иностранцам, прибывшим на территорию Российской Федерации должен быть предоставлен доступ с логином и паролем, который будет обозначен в въездном штампе в автоматическом порядке. Данные указанные в въездном штампе позволят в личном кабинете указывать информацию о местоположении.

Предоставление информации самим иностранцем является также положительным, что позволит снизить уровень правонарушений, связанный с фиктивной регистрацией. Привлекаются к ответственности, связанной с фиктивной регистрацией, в большинстве случаев иностранцы. Такое положение оставляет безнаказанными тех граждан Российской Федерации, кто ведет противоправную деятельность, тем самым подрывая принцип справедливости.

Исходя из вышеизложенного следует подчеркнуть, что вопросы миграционного характера будут приобретать более острый характер, из-за все возрастающей роли процессов глобализации и миграционных потоков. Большую роль при этом будут играть интеграционные процессы, где основным из них является Евразийский экономический союз, который одной из основной цели выделяет стремление к формированию единого рынка товаров, услуг, капитала и трудовых ресурсов в рамках Союза (Договор ЕАЭС, 2014).

\section{Благодарность.}

Исследование выполнено при поддержке компании 000 «Миграционно-визовый центр».

\section{СПИСОК ЛИТЕРАТУРЫ}

Конституция Российской Федерации (принята всенародным голосованием 12.12.1993) (с учетом поправок, внесенных Законами РФ о поправках к Конституции РФ № 6-ФКЗ от 30.12.2008, № 7-ФКЗ от 30.12.2008, №11-ФКЗ от 21.07.2014) (2014) // Собрание законодательства Российской Федерации, N 31, ст. 4398.

Федеральный закон «0 миграционном учете иностранных граждан и лиц без гражданства в Российской Федерации» от 18 июля 2006 г. N 109-Ф3: ред. от 01.05.2019 [Электронный ресурс] // Президент России. URL: http:// kremlin.ru/acts/bank/24033 (дата обращения: 25.10.2019). 
Урда, М. Н. (2019) Фиктивная постановка на миграционный и регистрационный учеты в контексте межотраслевого взаимодействия // Юридическая наука и правоохранительная практика. №2 (48). С. 85-91.

Трофимова, Т. С. (2019) Сущность и содержание миграционного учета в Российской Федерации // Образование. Наука. Научные кадры. №3. С. 47-49.

Федеральный закон от 27.06.2018 N 163-ФЗ О внесении изменений в федеральный закон «О миграционном учете иностранных граждан и лиц без гражданства в Российской Федерации» (2018) // Собрание законодательства Российской Федерации, N 27, ст. 3946.

Договор о Евразийском экономическом союзе, 29 мая 2014 г., г. Астана [Электронный ресурс] // Гарант. URL: http://base.garant.ru/70670880/ (дата обращения: 25.10.2019).

Дата поступления: 12.12.2019 2.

Никиенко Константин Геннадьевич - аспирант кафедры гражданского и предпринимательского права Московского гуманитарного университета. Адрес: 111395, Россия, г. Москва, ул. Юности , д. 5. Тел.: +7 (965) 39641-79. Эл. адрес: koc1nik@hotmail.com. Научный руководитель - к. ю. н., доцент А. А. Энгельгардт.

Nikienko Konstantin Gennadyevich, Postgraduate Student, Department of Civil and Business Law, Moscow University for the Humanities. Postal address: 5, Yunosti St., Moscow, Russian Federation, 111395. E-mail: koc1nik@hotmail.com. Scientific Advisor - A. A. Engelhardt, Candidate of Law, Associate Professor.

\section{Для цитирования:}

Никиенко К. Г. Проблемы миграционного учёта иностранцев по месту жительства и пребывания [Электронный ресурс] // Научные труды Московского гуманитарного университета. 2019. № 6. URL: http://journals.mosgu.ru/trudy/article/view/1099 (дата обращения: дд.мм.гг.). DOI: 10.17805/trudy.2019.6.8 